\title{
Induction of Soil Suppressiveness Against Rhizoctonia solani by Incorporation of Dried Plant Residues into Soil
}

\author{
Masahiro Kasuya, Andriantsoa R. Olivier, Yoko Ota, Motoaki Tojo, Hitoshi Honjo, and Ryo Fukui
}

First, second, third, fifth, and sixth authors: Department of Bioproductive Science, Utsunomiya University, Utsunomiya, Tochigi, 321-8505,
Japan; and fourth author: Graduate School of Life and Environmental Sciences, Osaka Prefecture University, Sakai, Osaka 599-8531,
Japan. Accepted for publication 6 July 2006.

\begin{abstract}
Kasuya, M., Olivier, A. R., Ota, Y., Tojo, M., Honjo, H., and Fukui, R. 2006. Induction of soil suppressiveness against Rhizoctonia solani by incorporation of dried plant residues into soil. Phytopathology 96:13721379 .

Suppressive effects of soil amendment with residues of 12 cultivars of Brassica rapa on damping-off of sugar beet were evaluated in soils infested with Rhizoctonia solani. Residues of clover and peanut were tested as noncruciferous controls. The incidence of damping-off was significantly and consistently suppressed in the soils amended with residues of clover, peanut, and B. rapa subsp. rapifera 'Saori', but only the vola-

nullified when antibacterial antibiotics were applied to the soils, suggesting that proliferation of antagonistic bacteria resident to the soils were responsible for disease suppression. When the seed (pericarps) colonized by $R$. solani in the infested soil without residues were replanted into the soils amended with such residues, damping-off was suppressed in all cases. In contrast, when seed that had been colonized by microorganisms in the soils containing the residues were replanted into the infested soil, damping-off was not suppressed. The evidence indicates that the laimosphere, but not the spermosphere, is the site for the antagonistic microbial interaction, which is the chief principle of soil suppressiveness against Rhizoctonia damping-off.
\end{abstract} tile substance produced from water-imbibed residue of cv. Saori exhibited a distinct inhibitory effect on mycelial growth of $R$. solani. Nonetheless, disease suppression in such residue-amended soils was diminished or
Additional keywords: glucosinolates, isothiocyanates.
Diseases caused by soilborne pathogens are the major constraint in establishing sustainable agriculture systems in which the use of chemical pesticides and fertilizers are to be limited to protect the environment for the future. Generally, these diseases are severe and often a limiting factor in conventional production systems, but are rare in undisturbed natural ecosystems $(8,9)$. Maintaining high levels of organic matter on the soil surface and incorporated into soil generally is associated with lower incidence and severity of root diseases (7). However, numerous reports have indicated that the management of crop residues or the addition of various types of organic amendments had either enhanced or suppressed diseases caused by soilborne pathogens (36). Meanwhile, there also are many examples of the value of incorporating organic matter, such as dry or green oat, barley, and maize; tree bark; and chicken manure for the control of such pathogens as Fusarium, Phytophthora, Pythium, Rhizoctonia, and Thielaviopsis spp. $(8,16,21,33)$. A number of recent reports also pointed out that various kinds of crop residues or composts incorporated into soil were shown to be effective in suppressing soilborne pathogens: hairy vetch (Vicia villosa) for Fusarium oxysporum (38), green manure or composts for Pythium graminicola (10), compost tea for P. ultimum (32), cotton-gin trash for Sclerotium rolfsii (5), and residue of broccoli for Verticillium dahliae (19). Soil or potting mixes amended with swine manure also suppressed $R$. solani (11) and $S$. rolfsii (5), and volatile fatty acids released from liquid swine manure killed microsclerotia of V. dahliae (35).

Among the crops used for residue amendment, cruciferous plants in particular have attracted interest because they are known

Corresponding author: R. Fukui; E-mail address: ryo@cc.utsunomiya-u.ac.jp

DOI: 10.1094/PHYTO-96-1372

(C) 2006 The American Phytopathological Society to contain glucosinolates, sulfur-containing secondary metabolites. Glucosinolates are hydrolyzed by the enzyme myrosinase to produce isothiocyanates (ITCs) (4), many of which are volatile and known to exhibit inhibitory effects on a wide variety of microbes, including soilborne pathogens $(23,30)$. For instance, hyphal growth of $F$. sambucinum grown in agar plates was suppressed when exposed to volatile fungicidal compounds released from macerate green leaf tissues of various Brassica plants (24). It was reported for $R$. solani that enzyme-degradation products of some glucosinolates were fungitoxic in in vitro tests (23) and suppressed soil colonization by this fungus in sterile soil (22). However, the exact roles of glucosinolates and their degradation products in suppression of $R$. solani diseases in natural soil are not yet understood clearly. Mazzola et al. (25) indicated that soil amendment with Brassica napus seed meal suppressed apple root rot caused by $R$. solani regardless of the glucosinolate content, suggesting that proliferation of soil microbes after seed meal amendment was responsible for disease suppression. Thus, glucosinolates in cruciferous plants may be related to growth inhibition of $R$. solani; however, their effects on disease suppression in the natural soil need to be examined in a controlled, sensitive experimental system.

One of the difficulties involved in an ecological study of $R$. solani is that the fungus exists in soil in various survival forms and no selective detection or isolation medium is available to measure its inoculum potential. A selective medium containing gallic acid (18) has been developed, but it was not effective for plate counting from soil samples in our preliminary tests. A sensitive method of assessing inoculum potential of $R$. solani in soil needs to be employed to evaluate the effects of soil treatment on disease incidence in relation to its inoculum potential.

The objective of this study was to examine the effects of soil amendment with the residues of various cruciferous plants on 
suppression of damping-off of sugar beet seedling caused by $R$. solani in natural soils. We specifically examined various cultivars of $B$. rapa because a variety of $B$. rapa cultivars are grown commercially and consumed in Japan and, thus, are available to compare effects among cultivars. Glucocinolate content of plant residues was determined and related to the resulting incidence of disease. The effects of plant residues incorporated into the soil on suppression of $R$. solani were evaluated by measuring dampingoff and pericarp colonization, representing the pathogenic and saprophytic activities of the pathogen, respectively, in order to assess the relationship between these two parameters and the site or sites of microbial interaction responsible for disease suppression.

\section{MATERIALS AND METHODS}

Soil. Two soils of Haplic Andosols, designated as $A_{0-M}$ and $B_{2}$ soils, used in this study were collected from different sections of paddy fields in the university farm (Mooka, Tochigi, Japan) during the fallow period. The $\mathrm{A}_{0-\mathrm{M}}$ soil was collected from a section that has been treated annually with organically composted cow manure, dead leaves, rice hull, rice straw, and wheat straw at 50 t/ha from 1991 to 1994 and at 20 t/ha thereafter. The $\mathrm{B}_{2}$ soil was collected from a section that has received application of the same compost at $30 \mathrm{t} / \mathrm{ha}$ in 1991 only and, thereafter, at 80 to $100 \mathrm{~kg} \mathrm{~N} / \mathrm{ha}$ per year, with a compound fertilizer $(\mathrm{N}: \mathrm{P}: \mathrm{K}=$ 10:18:16) applied in the top 15-cm soil layer every second row, plus a compound fertilizer (N:P:K = 5:20:20) applied as a side dressing. Only rice straw had been incorporated as organic matter since 1992 in this plot. Composite soil samples were collected from $\approx 10$ random locations in each section to a depth of $10 \mathrm{~cm}$. Lumps of soil were pulverized and dried for several days in the greenhouse before passing through a $2.0-\mathrm{mm}$ mesh sieve. Each of the prepared soils was stored in 50-liter plastic containers in a cool, shady place to maintain soil moisture.

Inoculum preparation. Isolate MAFF305222 of $R$. solani Kühn (AG2-2 IIIB) was obtained from the gene bank of the Ministry of Agriculture, Forestry, and Fishery at the National Institute of Agrobiological Sciences, Tsukuba, Ibaraki, Japan. For soil infestation, inoculum of this isolate was prepared as follows: a mixture of $180 \mathrm{~g}$ of barley grains and $150 \mathrm{~g}$ of distilled water in a 1-liter Erlenmeyer flask was autoclaved for $30 \mathrm{~min}$. After cooling, the grains were inoculated aseptically with six 5-mmdiameter disks of potato dextrose agar colonized by mycelia of $R$. solani and incubated for 2 weeks at $25^{\circ} \mathrm{C}$. The flask was shaken daily to avoid lumping of the grains caused by aerial growth of the mycelium. The grains, completely colonized with the fungus, were air dried at 30 to $32^{\circ} \mathrm{C}$ for $24 \mathrm{~h}$, ground using an osterizer-type blender (AS ONE, Osaka, Japan), and then passed through a $1.0-\mathrm{mm}$ mesh sieve. This inoculum was kept in a plastic container with desiccant at $-18^{\circ} \mathrm{C}$.

Plant residue. Twelve cultivars of Brassica rapa L. (Chisujikyoumizuna, Seppaku-taina, Kanzaki-hanana, Nozawana, Kukidachina, Hankekkyu-santousai, Shin-okute-aburana, Wase-aburana, Shougatuna, Ayumi, Saori, and Aoi) were used in this study (Table 1). In this article, these are denoted as Mizuna, Taina, Nabana, Nozawana, Touna, Santousai, Okute-aburana, Waseaburana, Shougatuna, Ayumi, Saori, and Aoi, respectively. Plants of $B$. rapa had been grown without insecticides or fungicides in a university experimental field (Utsunomiya, Tochigi, Japan) in 2002. Compound fertilizer was applied at $200 \mathrm{~kg} \mathrm{~N} / \mathrm{ha}$. Leaves and stems of plants were harvested and air dried in the laboratory at room temperature $\left(16\right.$ to $\left.24^{\circ} \mathrm{C}\right)$, ground with the blender, and passed through a $1.0-\mathrm{mm}$ mesh sieve to obtain a semi-powdered or flake form of each plant residue. The dried plant residues of 12 cultivars were stored individually in plastic bags in desiccators at room temperature until use. Dried residues of Arachis hypogaea L. 'Chiba-handachi' and Trifolium pratense L. 'Harukaze' (denoted as Peanut and Clover, respectively) were used as noncruciferous controls. After harvesting leaves and stems, the dried residues of these plants was prepared as described above.

Effects of plant residues incorporated into soil on dampingoff of sugar beet. Seed of Beta vulgaris L. 'Nozomi' were used to examine the incidence of pericarp colonization and damping-off of the seedlings in the infested soils in order to evaluate the effects of plant residues incorporated into soil on the saprophytic and pathogenic activities, respectively, of $R$. solani. Each soil $(800 \mathrm{~g})$ was placed in glass beakers and pasteurized in a water bath maintained at 65 to $70^{\circ} \mathrm{C}$ for $30 \mathrm{~min}$ to eliminate Pythium spp. Next day, the soil was amended with $8.0 \mathrm{~g}$ of each residue $(1 \%, \mathrm{wt} / \mathrm{wt})$ and $0.8 \mathrm{~g}$ of $R$. solani inoculum $(0.1 \%, \mathrm{wt} / \mathrm{wt})$ in a plastic bag and mixed first by hand. The soil mixture then was placed in aluminum cans and homogenized thoroughly using a tube rotator (AS ONE) for $10 \mathrm{~min}$. The infested soil without residues (nontreated) and the soil incorporated with residue of Peanut were prepared similarly in each test for comparison. Each plant residue was examined once, and those that induced suppression of damping-off in each soil were re-examined in a repeated test. Overall, five trials using $\mathrm{A}_{0-\mathrm{M}}$ soil and four trials using $\mathrm{B}_{2}$ soil were performed to examine the effects of all residues. Residue of Clover also was used as the noncruciferous control in several tests.

The tests for examining pericarp colonization and damping-off were done simultaneously. To examine pericarp colonization by $R$. solani, $800 \mathrm{~g}$ of the soil mixture was partitioned into eight

TABLE 1. Plant species and cultivars used to produce plant residues

\begin{tabular}{|c|c|c|c|}
\hline Plant family, species ${ }^{\mathrm{x}}$ & Cultivar & Genome type & Names used ${ }^{y}$ \\
\hline \multicolumn{4}{|l|}{ Brassicaceae } \\
\hline Brassica rapa $\mathrm{L}$. & Chisuji-kyoumizuna & AA & Mizuna \\
\hline B. rapa L. & Hankekkyu-santousai & AA & Santousai \\
\hline B. rapa $\mathrm{L}$. & Kukidachina & AA & Touna \\
\hline B. rapa $\mathrm{L}$. & Nozawana & AA & Nozawana \\
\hline B. rapa $\mathrm{L}$. & Seppaku-taina & AA & Taina \\
\hline B. rapa $\mathrm{L}$. & Shougatuna & AA & Shougatuna \\
\hline B. rapa subsp. rapifera ${ }^{\mathrm{Z}}$ & Aoi & AA & Aoi \\
\hline B. rapa subsp. rapifera & Ayumi & AA & Ayumi \\
\hline B. rapa subsp. rapifera & Saori & AA & Saori \\
\hline \multicolumn{4}{|l|}{ Leguminosae } \\
\hline Arachis hypogaea $\mathrm{L}$. & Chiba-handachi & $\cdots$ & Peanut \\
\hline Trifolium pratense $\mathrm{L}$. & Harukaze & $\cdots$ & Clover \\
\hline
\end{tabular}

x Seed of all Brassica spp. were obtained from Tohoku Seed Co., Tochigi, Japan.

${ }^{y}$ Names used in tables and figures.

${ }^{\text {z }}$ Crops of this subspecies are called "Komatsuna" in Japan. 
plastic cups (9 $\mathrm{cm}$ in diameter and $7 \mathrm{~cm}$ deep) and 15 seed were planted to a depth of $1 \mathrm{~cm}$. A small amount of water was added to the soil to adjust the soil water content to the equivalent of $-10 \mathrm{kPa}$ (48 and $44 \%$ for $\mathrm{B}_{2}$ and $\mathrm{A}_{0-\mathrm{M}}$ soils, respectively). The cups were covered with tight-fitting lids, and these microcosms were incubated at $22^{\circ} \mathrm{C}$. After $48 \mathrm{~h}$, the soils were passed through a sieve and washed with tap water to recover the whole seeds. Then, the true seeds were removed from the pericarps, and five of the pericarps were plated on $1.5 \%$ water agar containing streptomycin sulfate (Sigma-Aldrich, St. Louis) at $50 \mu \mathrm{g} \mathrm{ml}^{-1}$ and chloramphenicol (ICN Biomedicals, Aurora, OH) at $50 \mu \mathrm{g} \mathrm{m}^{-1}$. The frequency of pericarp colonization by $R$. solani or other fungi was enumerated for 2 days under a dissecting microscope based on the morphological characteristics of the hyphae growing out of the pericarps.

To examine damping-off on sugar beet seedlings, microcosms were prepared as described above except that the cups were placed in a temperature-regulated greenhouse room $\left(22\right.$ and $17^{\circ} \mathrm{C}$, day and night, respectively) without covering. The cups were watered each day to keep the moisture near $-10 \mathrm{kPa}$. The number of surviving seedlings and those killed by damping-off, judged by the typical "pinching-off" symptoms, were enumerated for 10 days after sowing. Percentage of emergence in noninfested soil was $>90 \%$. All tests were done with eight replicates in a randomized complete block (RCB) design.

Effects of antibiotics on suppression of damping-off in the residue-amended soils. To determine whether soil bacteria which may have proliferated in response to incorporation of the residues contributed to suppression of damping-off, the incidence of damping-off was assessed in the residue-incorporated soils treated with two antibacterial antibiotics. The residues of Saori, Taina, Touna, Clover, and Peanut were mixed into $\mathrm{A}_{0-\mathrm{M}}$ or $\mathrm{B}_{2}$ as described above. All of the procedures were the same, except that the soil was moistened with a solution containing streptomycin sulfate and chloramphenicol to attain a concentration of each antibiotic in the soil solution of $173 \mu \mathrm{g} \mathrm{ml}^{-1}$. The cups containing the soils were placed in a greenhouse at 17 and $22^{\circ} \mathrm{C}$, and the incidence of damping-off was recorded 10 days after sowing. The tests were done with eight replicates in an RCB design.

Inhibition of mycelial growth of $R$. solani by volatile substances produced from plant residues. Water agar $(30 \mathrm{ml})$, melted and cooled to $48^{\circ} \mathrm{C}$, was mixed with $1 \mathrm{~g}$ of fungal inoculum and poured into petri dishes. Agar disks containing the inoculum were obtained using a 5-mm-diameter cork borer and plated at the center of water agar plates. On the inner surface of inverted lids of the plates, $3 \mathrm{ml}$ of an antibiotic solution containing cycloheximide (Sigma-Aldrich) at $100 \mu \mathrm{g} \mathrm{ml}^{-1}$, thiabendazole (Sigma-Aldrich) at $100 \mu \mathrm{g} \mathrm{ml}^{-1}$, streptomycin sulfate at $50 \mu \mathrm{g} \mathrm{ml}^{-1}$, and chloramphenicol at $100 \mu \mathrm{g} \mathrm{ml}^{-1}$ were pipetted, and then individual residues of Nabana, Taina, Touna, Ayumi, Saori, Clover, and Peanut were sprinkled onto the inverted lids. The amount of residue tested was either 20,50 , or $500 \mathrm{mg}$, and dishes with either the antibiotic solution only or with distilled water were prepared as the controls. The bottoms of the petri dishes containing agar with the inoculum disks then were placed upside down onto the inverted lids containing the residue or antibiotic solution. The dishes were sealed with parafilm and incubated at $22^{\circ} \mathrm{C}$. The plates were observed for radial mycelial growth of $R$. solani $24 \mathrm{~h}$ after inoculation and thereafter every $12 \mathrm{~h}$ to record the maximum diameter of the fungal colony in each plate. Each residue or fungal treatment was replicated three times.

Inhibition of mycelial growth of $R$. solani by water-soluble substances exuded from plant residues. Water-soluble substances were extracted by steeping $1 \mathrm{~g}$ of individual plant residues of Nabana, Taina, Mizuna, Ayumi, Saori, Clover, and Peanut in $10 \mathrm{ml}$ of distilled water in test tubes. The mixtures were shaken well and kept in a refrigerator at $5^{\circ} \mathrm{C}$ for $6 \mathrm{~h}$. A 5-ml aliquot of each exudate was carefully pipetted from the bottom of the tubes, placed in centrifuge tubes, and centrifuged for $10 \mathrm{~min}$ at $10,000 \mathrm{rpm}$. The supernatants were filtered individually through millipore filters $(0.2-\mu \mathrm{m}$ pore size) to remove microbes and impurities. From each of these extracts, 10- and 100-fold dilutions were prepared in distilled water. These two dilutions, the original extract, and distilled water as a control were absorbed into $10-\mathrm{mm}-$ diameter, sterile paper disks, and each was placed at four diagonal peripheries on a water agar plate. A water agar disk containing the fungal inoculum was inoculated in the center of the water agar plate, which then was incubated at $22^{\circ} \mathrm{C}$. The plates were observed 72, 84, and $96 \mathrm{~h}$ after inoculation for any apparent inhibition of mycelial growth around the paper disks. Each treatment was replicated three times.

The site of microbial interaction responsible for disease suppression. To determine the site of microbial interaction, seed that had been colonized by $R$. solani in the soil without residue amendment were replanted into the soils containing the residues. In this test, $800 \mathrm{~g}$ of $\mathrm{A}_{0-\mathrm{M}}$ soil infested with $0.8 \mathrm{~g}$ of fungal inoculum as described previously was moistened to establish a soil water potential of $-10 \mathrm{kPa}$ in a plastic container ( 30 by 22 by $10 \mathrm{~cm}$ ). Three containers with soil were prepared. In all, 850 seed of sugar beet were sown in these soils and incubated at $22^{\circ} \mathrm{C}$ to encourage pericarp colonization by $R$. solani. After $24 \mathrm{~h}$, seed were recovered from the soils by wet-sieving using tap water for $1 \mathrm{~min}$ and transplanted into the pasteurized soil amended with the residue of Saori, Taina, Nabana, Clover, or Peanut. Nontreated soil, without residue amendment, was used as the control, and the incidence of damping-off for each treatment was determined with eight replicates (120 seed in total) as described previously. Upon reseeding, a subset of 120 seed recovered from infested soil was plated directly onto water agar plates with antibiotics to determine the percentage of colonization of pericarps by $R$. solani. The test was repeated with a higher inoculum concentration $(0.5 \mathrm{~g}$ per $100 \mathrm{~g}$ of soil).

A complementary test was performed by reversing the order of soil treatments to examine whether the microorganisms colonizing the pericarp had any effect on suppression of damping-off by $R$. solani. First, seed were sown in $\mathrm{A}_{0-\mathrm{M}}$ soil mixed with the residues of the same five plants and dispensed into eight individual cups. These residue-containing soils were moistened and incubated at $22^{\circ} \mathrm{C}$ as described previously. Seed sown in the soil without residue amendments and those soaked in sterile distilled water were prepared as the nontreated and water control seed, respectively. After $24 \mathrm{~h}$, the seed were recovered by passing the soils through a $2.0-\mathrm{mm}$ mesh sieve without washing and quickly transplanted to the pasteurized soil infested with $R$. solani. The cups containing the soils were placed in the greenhouse, and the incidence of damping-off was determined with eight replicates (120 seed in total) as described previously.

Quantification of total glucosinolates in residues. All residues used to test the inhibitory effect of volatile substances were assayed for total glucosinolate content by measuring the amount of ITCs released by hydrolysis. The glucosinolates in $5 \mathrm{~g}$ of residue powder were extracted following the method described by Palmieri (29), with modifications. Myrosinase enzyme was prepared from $5 \mathrm{~g}$ of brown mustard powder (S\&B Foods Inc., Tokyo) suspended in distilled water and extracted by the method described by Appelqvist and Josefsson (3). The cake thus obtained was dissolved in $200 \mathrm{ml}$ of phosphate buffer. Plant extracts were washed with an equal volume of ethyl ether. The hydrolysis reaction then was performed by mixing $2 \mathrm{ml}$ of glucosinolate extract, $1 \mathrm{ml}$ of $100 \mathrm{mM}$ phosphate buffer, $1 \mathrm{ml}$ of myrosinase, and $1 \mathrm{ml}$ of $25 \mathrm{mM}$ ascorbic acid in a beaker in a water bath maintained at $37^{\circ} \mathrm{C}$ for $60 \mathrm{~min}$. The ITCs released by hydrolysis were extracted with $4 \mathrm{ml}$ of ethyl acetate. After a cyclocondensation reaction with 1,2-benzenedithiol (34), the concentration of ITCs was determined by high-performance liquid 
chromatography (JASCO LG-2080-02) at $365 \mathrm{~nm}$ using a column YMC Pack (150 by $4.6 \mathrm{~cm})$. The eluting solvent, methanol/milliQ water (70/30 by volume), was delivered at a flow rate of $0.75 \mathrm{ml} / \mathrm{min}$. Standard solutions prepared with 2-phenylethyl ITCs were included in the cyclocondensation treatment, and the amount of ITCs formed was determined using the analytical curve.

Data analysis. Analysis of variance (ANOVA) was used to examine the effect of the main treatment for all tests. Two-way ANOVA (plant residue-antibiotics) was used to examine the effects of plant residues and antibiotics on damping-off. Incubation period was considered as the repeated measure factor in a test examining the effects of volatiles from the residues on mycelial growth. Means in multiple comparison were separated by the Student-Newman-Keuls test and means in pairwise comparison were compared by Fisher's protected least significant difference (LSD) test at $P=0.05$.

\section{RESULTS}

Suppression of damping-off in soils amended with plant residues. Incorporation of residues of Taina, Touna, Okuteaburana, Santousai, Shougatuna, Aoi, or Peanut in $\mathrm{A}_{0-\mathrm{M}}$ soil significantly reduced the incidence of pericarp colonization by $R$. solani in at least one experiment (Table 2). Soil amended with residues of Saori or Ayumi was highly suppressive to pericarp colonization in both trials in which they were applied. Residue of

TABLE 2. Incidence of pericarp colonization by Rhizoctonia solani and other fungal species, and incidence of damping-off in $\mathrm{A}_{0-\mathrm{M}}$ soil ${ }^{\mathrm{y}}$

\begin{tabular}{|c|c|c|c|}
\hline \multirow[b]{2}{*}{ Plant residue } & \multirow[b]{2}{*}{ Damping-off ${ }^{z}$} & \multicolumn{2}{|c|}{$\begin{array}{l}\text { No. of pericarps (per } 15 \text { seed) } \\
\text { colonized by }\end{array}$} \\
\hline & & R. solani & Other fungi \\
\hline \multicolumn{4}{|l|}{ First experiment } \\
\hline Nabana & $15.0 \mathrm{~b}$ & $11.6 \mathrm{ab}$ & $9.1 \mathrm{bc}$ \\
\hline Mizuna & $14.6 \mathrm{~b}$ & $12.0 \mathrm{ab}$ & $7.9 \mathrm{~b}$ \\
\hline Taina & $14.5 \mathrm{~b}$ & $9.4 \mathrm{a}$ & $11.9 \mathrm{c}$ \\
\hline Peanut & $9.3 \mathrm{a}$ & $9.6 \mathrm{a}$ & $10.5 \mathrm{bc}$ \\
\hline Nontreated & $13.3 \mathrm{~b}$ & $14.0 \mathrm{~b}$ & $0.0 \mathrm{a}$ \\
\hline \multicolumn{4}{|c|}{ Second experiment } \\
\hline Touna & $14.8 \mathrm{~b}$ & $3.4 \mathrm{a}$ & $1.8 \mathrm{a}$ \\
\hline Okute-aburana & $13.8 \mathrm{~b}$ & $3.9 \mathrm{a}$ & $6.9 \mathrm{~b}$ \\
\hline Wase-aburana & $13.8 \mathrm{~b}$ & $9.6 \mathrm{~b}$ & $1.4 \mathrm{a}$ \\
\hline Nozawana & $13.0 \mathrm{~b}$ & $7.0 \mathrm{ab}$ & $5.9 \mathrm{~b}$ \\
\hline Peanut & $2.9 \mathrm{a}$ & $3.8 \mathrm{a}$ & $14.0 \mathrm{c}$ \\
\hline Nontreated & $13.6 \mathrm{~b}$ & $9.9 \mathrm{~b}$ & $0.4 \mathrm{a}$ \\
\hline \multicolumn{4}{|l|}{ Third experiment } \\
\hline Santousai & $14.6 \mathrm{c}$ & $6.3 \mathrm{~b}$ & $2.1 \mathrm{~b}$ \\
\hline Shougatuna & $14.3 \mathrm{c}$ & $6.5 \mathrm{~b}$ & $3.3 \mathrm{~b}$ \\
\hline Ayumi & $3.4 \mathrm{a}$ & $2.6 \mathrm{a}$ & $12.6 \mathrm{c}$ \\
\hline Saori & $1.8 \mathrm{a}$ & $2.6 \mathrm{a}$ & $12.5 \mathrm{c}$ \\
\hline Peanut & $1.6 \mathrm{a}$ & $4.1 \mathrm{ab}$ & $13.1 \mathrm{c}$ \\
\hline Nontreated & $8.0 \mathrm{~b}$ & $12.5 \mathrm{c}$ & $0.0 \mathrm{a}$ \\
\hline \multicolumn{4}{|l|}{ Fourth experiment } \\
\hline Touna & $12.4 \mathrm{~d}$ & $5.9 \mathrm{a}$ & $3.6 \mathrm{a}$ \\
\hline Taina & $9.3 \mathrm{c}$ & $4.3 \mathrm{a}$ & $12.5 \mathrm{c}$ \\
\hline Okute-aburana & $6.6 \mathrm{~b}$ & $5.0 \mathrm{a}$ & $9.6 \mathrm{~b}$ \\
\hline Clover & $4.8 \mathrm{~b}$ & $9.5 \mathrm{~b}$ & $3.3 \mathrm{a}$ \\
\hline Peanut & $2.3 \mathrm{a}$ & $9.6 \mathrm{~b}$ & $9.5 \mathrm{~b}$ \\
\hline Nontreated & $13.4 \mathrm{~d}$ & $7.1 \mathrm{ab}$ & $0.9 \mathrm{a}$ \\
\hline \multicolumn{4}{|l|}{ Fifth experiment } \\
\hline Aoi & $7.0 \mathrm{~b}$ & $10.3 \mathrm{~b}$ & $3.5 \mathrm{~b}$ \\
\hline Ayumi & $6.9 \mathrm{~b}$ & $5.5 \mathrm{a}$ & $11.0 \mathrm{c}$ \\
\hline Saori & $6.3 \mathrm{~b}$ & $3.0 \mathrm{a}$ & $11.8 \mathrm{c}$ \\
\hline Clover & $4.3 \mathrm{a}$ & $11.6 \mathrm{bc}$ & $2.4 \mathrm{~b}$ \\
\hline Peanut & $3.1 \mathrm{a}$ & $11.9 \mathrm{bc}$ & $9.9 \mathrm{c}$ \\
\hline Nontreated & $13.4 \mathrm{c}$ & $14.8 \mathrm{c}$ & $0.3 \mathrm{a}$ \\
\hline
\end{tabular}

y Numbers are means of eight replicates (120 seed or seedlings in total). The $F$ value is significant at $P<0.002$ for each test in all experiments, except for the test for pericarp colonization by $R$. solani in the first experiment $(P=$ 0.007). Means followed by the same letters in each column are not significantly different according to Student-Newman-Keuls test $(P=0.05)$.

${ }^{\mathrm{z}}$ Number with damping-off (per 15 seed).
Clover did not reduce pericarp colonization in either of two consecutive trials with $\mathrm{A}_{0-\mathrm{M}}$ soil. The incidence of pericarp colonization by other fungi was nil or negligible in the nontreated pasteurized soil, but was markedly increased in at least two trials when the residues of Ayumi, Saori, Taina, Okute-aburana, and Peanut were incorporated into soil. No hyphae of Pythium spp. growing from pericarps were observed in any tests.

Damping-off was significantly suppressed in at least two trials by incorporating residues of Ayumi, Saori, Peanut, or Clover into $\mathrm{A}_{0-\mathrm{M}}$ soil (Table 2). Disease suppression by soil incorporation of residues of Taina or Okute-aburana was evident only once in two trials.

The incidence of pericarp colonization by $R$. solani in $\mathrm{B}_{2}$ soil was significantly reduced in at least one trial for all plant residues except for that of Wase-aburana (Table 3). The incidence was significantly reduced in two trials when the residue of Ayumi or Saori was incorporated into soil, but the residue of Peanut significantly suppressed pericarp colonization in three of four trials. The incidence of pericarp colonization by other fungi was markedly increased by incorporating all residues except for those of Touna and Wase-aburana. Incorporation of clover residue into $\mathrm{B}_{2}$ soil suppressed pericarp colonization in one of two trials. No hyphae of Pythium spp. growing out of pericarps were observed in any tests.

Incorporation of the residues of Saori, Clover, or Peanut into $\mathrm{B}_{2}$ soil resulted in significant suppression of damping-off in at least two experiments (Table 3 ). The residue of peanut induced soil suppressiveness in each of four trials. Meanwhile, soil treatment with the residues of Mizuna, Taina, Santousai, and Ayumi also significantly reduced disease incidence once, but the effect induced by the residue of Ayumi or Taina was not reproduced in a second trial.

TABLE 3. Incidence of pericarp colonization by Rhizoctonia solani and other fungal species, and incidence of damping-off in $\mathrm{B}_{2}$ soil ${ }^{\mathrm{y}}$

\begin{tabular}{|c|c|c|c|}
\hline \multirow[b]{2}{*}{ Plant residue } & \multirow[b]{2}{*}{ Damping-off ${ }^{\mathrm{Z}}$} & \multicolumn{2}{|c|}{$\begin{array}{l}\text { No. of pericarps (per } 15 \text { seed) } \\
\text { colonized by }\end{array}$} \\
\hline & & $R$. solani & Other fungi \\
\hline \multicolumn{4}{|l|}{ First experiment } \\
\hline Taina & $10.1 \mathrm{~b}$ & $11.8 \mathrm{bc}$ & $7.4 \mathrm{c}$ \\
\hline Mizuna & $9.9 \mathrm{~b}$ & $7.3 \mathrm{a}$ & $10.6 \mathrm{~d}$ \\
\hline Nabana & $8.1 \mathrm{~b}$ & $9.6 \mathrm{~b}$ & $7.9 \mathrm{c}$ \\
\hline Clover & $5.4 \mathrm{a}$ & $11.8 \mathrm{bc}$ & $3.6 \mathrm{~b}$ \\
\hline Peanut & $4.6 \mathrm{a}$ & $11.3 \mathrm{~b}$ & $13.5 \mathrm{e}$ \\
\hline Nontreated & $13.8 \mathrm{c}$ & $14.0 \mathrm{c}$ & $0.6 \mathrm{a}$ \\
\hline \multicolumn{4}{|c|}{ Second experiment } \\
\hline Wase-aburana & $12.1 \mathrm{~b}$ & $12.6 \mathrm{bc}$ & $3.1 \mathrm{ab}$ \\
\hline Touna & $11.6 \mathrm{~b}$ & $9.3 \mathrm{ab}$ & $2.5 \mathrm{ab}$ \\
\hline Nozawana & $11.3 \mathrm{~b}$ & $6.5 \mathrm{a}$ & $4.9 \mathrm{bc}$ \\
\hline Okute-aburana & $10.0 \mathrm{~b}$ & $7.9 \mathrm{a}$ & $6.0 \mathrm{c}$ \\
\hline Peanut & $1.5 \mathrm{a}$ & $9.9 \mathrm{abc}$ & $11.4 \mathrm{~d}$ \\
\hline Nontreated & $12.6 \mathrm{~b}$ & $13.1 \mathrm{c}$ & $0.8 \mathrm{a}$ \\
\hline \multicolumn{4}{|l|}{ Third experiment } \\
\hline Shougatuna & $10.3 \mathrm{c}$ & $2.3 \mathrm{ab}$ & $13.5 \mathrm{~b}$ \\
\hline Santousai & $6.8 \mathrm{~b}$ & $3.0 \mathrm{ab}$ & $13.4 \mathrm{~b}$ \\
\hline Saori & $6.1 \mathrm{~b}$ & $1.1 \mathrm{a}$ & $14.3 \mathrm{~b}$ \\
\hline Ayumi & $5.1 \mathrm{~b}$ & $2.5 \mathrm{ab}$ & $14.1 \mathrm{~b}$ \\
\hline Peanut & $1.8 \mathrm{a}$ & $4.1 \mathrm{~b}$ & $13.4 \mathrm{~b}$ \\
\hline Nontreated & $12.3 \mathrm{c}$ & $8.3 \mathrm{c}$ & $8.3 \mathrm{a}$ \\
\hline \multicolumn{4}{|c|}{ Fourth experiment } \\
\hline Ayumi & $12.8 \mathrm{c}$ & $5.4 \mathrm{~b}$ & $11.1 \mathrm{~b}$ \\
\hline Taina & $12.4 \mathrm{c}$ & $6.4 \mathrm{~b}$ & $12.1 \mathrm{bc}$ \\
\hline Saori & $8.0 \mathrm{~b}$ & $2.8 \mathrm{a}$ & $13.5 \mathrm{c}$ \\
\hline Clover & $7.5 \mathrm{~b}$ & $5.8 \mathrm{~b}$ & $12.3 \mathrm{bc}$ \\
\hline Peanut & $3.5 \mathrm{a}$ & $5.5 \mathrm{~b}$ & $13.1 \mathrm{c}$ \\
\hline Nontreated & $13.6 \mathrm{c}$ & $13.0 \mathrm{c}$ & $5.9 \mathrm{a}$ \\
\hline
\end{tabular}

y Numbers are means of eight replicates (120 seed or seedlings in total). The $F$ value is significant at $P<0.001$ for all tests in all experiments. Means followed by the same letters in each column are not significantly different according to Student-Newman-Keuls test $(P=0.05)$.

${ }^{\mathrm{z}}$ Number with damping-off (per 15 seed). 
Overall, there were no clear relationships between the frequency of pericarp colonization and the incidence of damping-off in the residue-amended soils.

Effects of soil treatment with antibiotics on disease suppression. Suppression of damping-off induced by soil treatment with the residues of Saori, Taina, or Clover essentially was nullified by applying two antibiotics to both soils (Table 4). In these treatments, disease incidence was similar to that for the nontreated soils. In contrast, disease suppression induced by soil treatment with the residue of Peanut was significantly diminished by the antibiotic treatment but not nullified when compared with disease incidence in the nontreated soils with or without the antibiotics. The residue of Touna did not induce disease suppression in either soil, and treatment with antibiotics of the soils into which this residue was incorporated resulted in disease incidence similar to that in the nontreated soils.

Inhibition of mycelial growth of $R$. solani by volatile and water-soluble substances from plant residues. Inhibition of mycelial growth by volatile substances was observed for all plant residues when the fungus was exposed to $500 \mathrm{mg}$ of the residue (Fig. 1A). The inhibitory effect was greatest for the residue of Saori and least for that of Peanut. Upon exposure to volatiles from $50 \mathrm{mg}$ of the residues, only the residue of Saori inhibited growth of $R$. solani (Fig. 1B). Exposure to $20 \mathrm{mg}$ of the residues did not have any inhibitory effects on mycelial growth for any of the plant residues (Fig. 1C).

Apparent inhibition of mycelial growth by water-soluble substances was not evident for any plant resides.

Site of microbial interaction responsible for disease suppression. Damping-off was suppressed significantly in soil amended with the residues of Saori, Taina, Nabana, Clover, or Peanut when the seed that had been colonized by $R$. solani prior to sowing were used as inoculum (Table 5). The incidence of damping-off in nontreated soil was 40 of 120 seedlings $(33.3 \%)$ and the frequency of pericarp colonization in the inoculum seed was 64 of 120 seed $(53.3 \%)$. When the inoculum in the soil was increased to $0.5 \mathrm{~g}$ to enhance pericarp colonization of the seed that were to be replanted, the residues of all plants but Taina induced suppression of damping-off. In this case, the frequency of pericarp colonization was $78.7 \%$. In contrast, when seed colonized by microorganisms in the respective residue-incorporated soils were transplanted into soil infested with $R$. solani, no disease suppression was evident (Table 6).

Total glucosinolates in residues. The quantities of total ITCs identified in individual plant residues ranged from not detected in Peanut to $13.626 \mu \mathrm{mol} \mathrm{g}^{-1}$ in Saori residue (Table 7).

\section{DISCUSSION}

Damping-off of sugar beet seedlings was suppressed by incorporation of specific plant residues into soil, and their effects were

TABLE 4. Effect of treatment of soil with antibiotics on incidence of damping-off caused by Rhizoctonia solani in $\mathrm{A}_{0-\mathrm{M}}$ and $\mathrm{B}_{2}$ soil $^{\mathrm{Z}}$

\begin{tabular}{lccccc}
\hline & \multicolumn{2}{c}{ Number with damping-off in soil without or with antibiotics } \\
\cline { 2 - 3 } \cline { 5 - 6 } \cline { 5 - 6 } Plant residue & \multicolumn{2}{c}{$\mathrm{A}_{0-\mathrm{M}}$ soil } & & \multicolumn{2}{c}{$\mathrm{B}_{2}$ soil } \\
\cline { 2 - 3 } \cline { 5 - 6 } Touna & $11.3 \mathrm{~d}$ & $15.0 \mathrm{f}$ & & $11.4 \mathrm{de}$ & $14.8 \mathrm{~g}$ \\
Taina & $6.6 \mathrm{c}$ & $14.5 \mathrm{ef}$ & & $7.5 \mathrm{c}$ & $14.4 \mathrm{fg}$ \\
Saori & $4.6 \mathrm{~b}$ & $12.9 \mathrm{def}$ & & $3.8 \mathrm{~b}$ & $12.3 \mathrm{ef}$ \\
Clover & $1.5 \mathrm{a}$ & $14.1 \mathrm{ef}$ & & $6.4 \mathrm{c}$ & $14.0 \mathrm{fg}$ \\
Peanut & $1.5 \mathrm{a}$ & $7.0 \mathrm{c}$ & & $1.1 \mathrm{a}$ & $10.1 \mathrm{~d}$ \\
Nontreated & $12.3 \mathrm{de}$ & $14.8 \mathrm{f}$ & & $12.3 \mathrm{ef}$ & $14.8 \mathrm{~g}$ \\
\hline z Numbers are means of eight replicates $(15$ seed per replicate, 120 seedlings \\
in total). For both experiments, the $F$ values for the cultivar and soil treat- \\
ment with antibiotics are significant at $P<0.001$, with a significant interac- \\
tion $(P<0.001)$. Means followed by the same letters for each soil are not \\
significantly different according to Student-Newman-Keuls test $(P=0.05)$.
\end{tabular}

similar in two comparable soils with different fertilization schemes. The cruciferous plants tested in this study all belonged to $B$. rapa (AA genome), but the suppressive effect was different depending on the cultivar from which each residue was prepared. Moreover, the residues of Clover and Peanut also induced soil suppressiveness consistently. These results clearly indicate that disease suppression was not specific to plant genome. Nonetheless, among all B. rapa cultivars, the residue of Ayumi provided the highest and most consistent disease suppression throughout the study, suggesting that the effect may be cultivar specific. A similar phenomenon was described for Rhizoctonia root rot of apple. Mazzola and $\mathrm{Gu}$ (26) reported that suppression of $R$. solani AG-5 or AG-8 in the soil was specific to the wheat cultivars (genotypes) that had been cultivated three times at 28-day cycles in that soil. In this study, however, the cruciferous crops tested
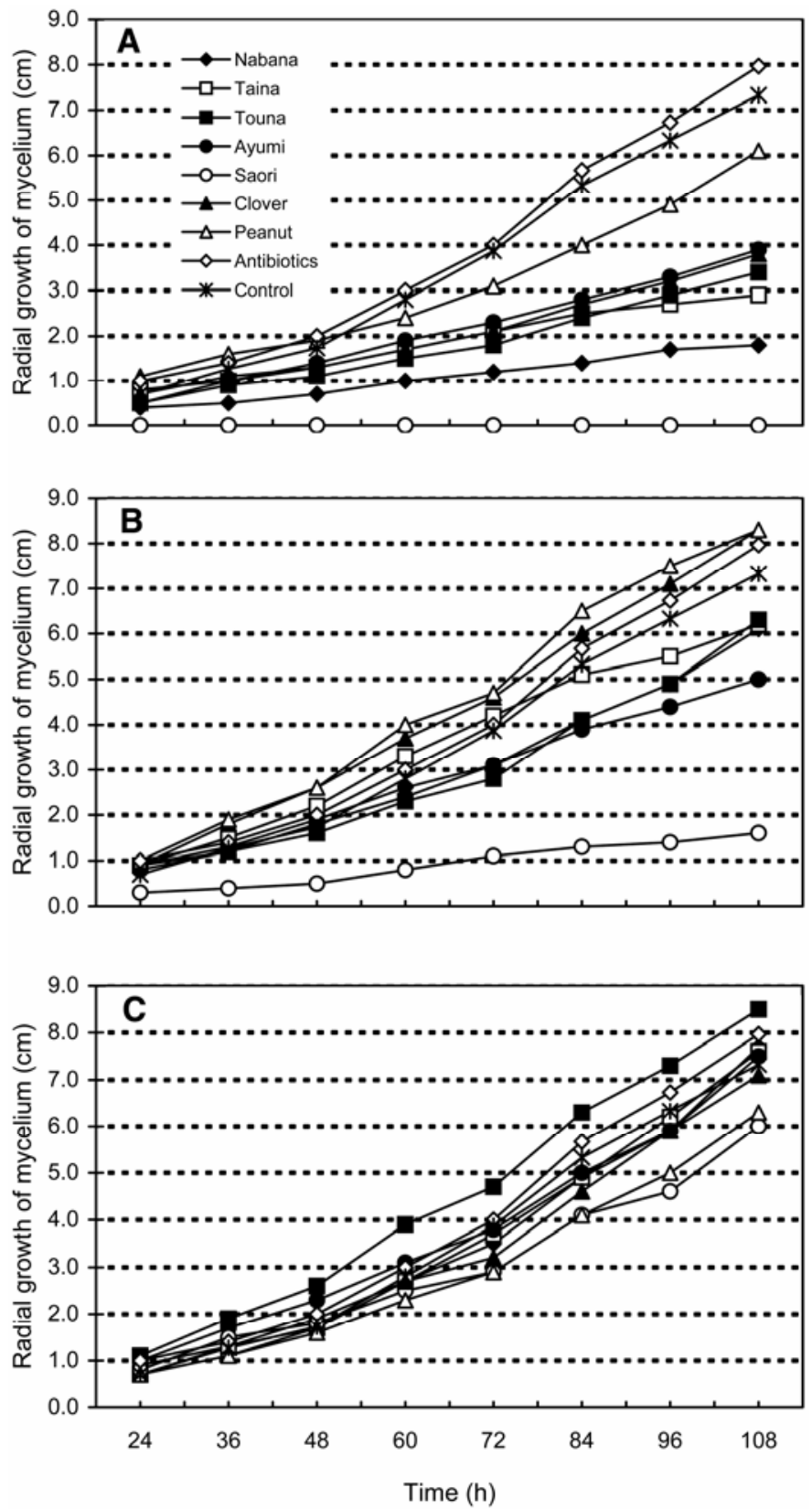

Fig. 1. Effects of volatile compounds released from water-imbibed plant residues on mycelial growth of Rhizoctonia solani in vitro: A, 500; B, 50; and C, $20 \mathrm{mg}$ of residue. Data points are the mean of three replicates. The least significant difference values are 1.37 and 1.44 for the data sets of $\mathbf{A}$ and $\mathbf{B}$, respectively, and the main effect was not significant for the data set of $\mathbf{C}$. The same data for the treatment with antibiotics and the water control are shown in all three graphs. 
were limited to those with the AA genome, and the effects of some cultivars (e.g., Ayumi and Taina) varied according to time and the soil used. More tests to examine other plant residues (including those with the CC or RR genomes) and their effects in different soils are needed to verify that disease suppression by soil amendment with the residues of cruciferous crops is specific to the cultivar.

The soil treatment of two antibacterial antibiotics revealed that suppression of damping-off was due chiefly to the bacterial proliferation in the soil in response to incorporation of the plant residue, and there was no evidence indicating that water-soluble compounds released from the plant residues were involved in disease suppression. In addition, such microbial proliferations appeared to be specific to the kind of residue. For instance, disease suppression induced by soil amendment with the residue of Saori was reversed by addition of the antibiotics to the soil, and this plant residue also enhanced fungal activities in the spermosphere in all tests. However, the enhanced fungal activities were not related to disease suppression. In contrast, the antibiotics also nullified disease suppression induced by the residue of Clover, which did not enhance fungal activities in most tests. Therefore, growth of antagonistic bacteria is responsible for disease suppression in both cases. On the other hand, the residue of Peanut always enhanced fungal activities, but disease suppression was not totally reversed by the antibiotics, suggesting that factors other than bacterial proliferation, probably of fungal origin, are involved in soil suppressiveness induced by this residue. These results clearly suggest that the course and consequence of microbial proliferation vary depending on the plant residue incorporated into the soil, leading to distinct soil microbial communities. This is comparable with the finding in the aforementioned study on Rhizoctonia root rot of apple (26). It also has been known locally in Latin American countries that diseases caused by $R$. solani do not occur in the areas where Euphorbia heterophylla has been growing (36). For suppression of apple root rot, it was elucidated that streptomycetes were responsible for disease suppression in the wheat-grown soils (7). All these observations suggest that the increase or decrease of diseases caused by $R$. solani are linked closely to cultivation practices and the plants (i.e., crops and weeds) growing in the soil.

Microbial proliferation and interactions in the bulk soil, but not in the spermosphere, are important for suppression of dampingoff. When the microorganisms proliferating in the spermosphere were transferred with the seed to infested soil, no effects on

TABLE 5. Effects of various plant residues incorporated into $\mathrm{A}_{0-\mathrm{M}}$ soil on damping-off of sugar beet seedlings when the seed colonized by Rhizoctonia solani were replanted to the residue-amended soils

\begin{tabular}{lc}
\hline Plant residue & No. with damping-off (in 15 seed $)^{\mathrm{x}}$ \\
\hline First experiment ${ }^{\mathrm{y}}$ & \\
Taina & $1.1 \mathrm{a}$ \\
Saori & $0.9 \mathrm{a}$ \\
Nabana & $0.9 \mathrm{a}$ \\
Clover & $0.8 \mathrm{a}$ \\
Peanut & $0.3 \mathrm{a}$ \\
Nontreated & $5.0 \mathrm{~b}$ \\
Second experiment ${ }^{\mathrm{z}}$ & $7.4 \mathrm{~b}$ \\
Taina & $3.8 \mathrm{a}$ \\
Saori & $2.9 \mathrm{a}$ \\
Nabana & $1.8 \mathrm{a}$ \\
Clover & $1.8 \mathrm{a}$ \\
Peanut & $8.1 \mathrm{~b}$ \\
Nontreated &
\end{tabular}

${ }^{\mathrm{x}}$ Numbers are means of eight replicates (120 seedlings in total). For each experiment, the $F$ value is significant at $P<0.001$. Means followed by the same letters are not significantly different according to Student-NewmanKeuls test $(P=0.05)$.

${ }^{\mathrm{y}}$ Frequency of pericarp colonization by $R$. solani before replanting was $53 \%$.

${ }^{\mathrm{z}}$ Frequency of pericarp colonization by $R$. solani before replanting was $79 \%$. damping-off were evident regardless of the plant residues incorporated into the soil. In contrast, the microorganisms proliferating in the soil in response to soil amendment with the residues capable of inducing soil suppressiveness significantly reduced the incidence of damping-off when the seed colonized by the pathogen were replanted to the residue-amended soils. It is noteworthy that the incidence of damping-off was significantly less in both nontreated natural soils than in the same soils treated with antibiotics, indicating the presence of indigenous suppressiveness in these natural soils. Such suppressiveness of soil commonly is referred to as general suppression $(8,17,31)$, which is caused by more than one microorganism $(2,8)$ and enhanced by the addition of organic matter (31). These results suggest that the microbial interactions responsible for disease suppression occur in the soil or, more specifically, in the laimosphere. Thus, the fungi colonizing the pericarp in the soil amended with the residue of Peanut may not be related to soil suppressiveness. The results also indicate that damping-off still can be prevented even when the pericarp already has been colonized by the pathogen, suggesting that damping-off by $R$. solani can be controlled by drenching the soil near the stem with biocontrol agents, and seed treatment with such agents is likely to be less effective than soil treatment.

In the process of damping-off, the mechanism for suppressing the pathogenic activity of $R$. solani differs from that of reducing its saprophytic activity. This aspect contrasts with the process during the events of damping-off caused by Pythium spp. For the latter, the frequency of seed colonization is directly related to the number of propagules until the colonization frequency reaches its maximum (13), and it also is correlated to the incidence of damping-off $(14,28)$. Hence, different approaches to biological control need to be employed for $R$. solani and Pythium spp. Microorganisms capable of suppressing these two kinds of pathogens also are known to be different. It was demonstrated that, although all of $>70$ different commercial composted pine barkamended potting mixes were effective in controlling damping-off of radish by Pythium spp., only one-fifth of those provided adequate control of $R$. solani damping-off because the latter was controlled by a much narrower spectrum of antagonistic micro-

TABLE 6. Effects of microorganisms colonizing the pericarp of sugar beet seed during incubation in the residue-amended soils on damping-off of the seedlings when the seed were replanted into the $\mathrm{A}_{0-\mathrm{M}}$ soil infested with Rhizoctonia solani

\begin{tabular}{lc}
\hline Plant residue & No. with damping-off (in 15 seed) \\
\hline Taina & $13.3 \mathrm{~b}$ \\
Saori & $14.6 \mathrm{~b}$ \\
Clover & $14.4 \mathrm{~b}$ \\
Peanut & $14.1 \mathrm{~b}$ \\
Nontreated & $13.6 \mathrm{ab}$ \\
Water control $^{\mathrm{z}}$ & $12.5 \mathrm{a}$ \\
\hline
\end{tabular}

y Numbers are means of eight replicates (120 seedlings in total). The $F$ value is significant at $P=0.023$, and means followed by the same letters are not significantly different according to Student-Newman-Keuls test $(P=0.05)$.

${ }^{\mathrm{z}}$ Seed were soaked for $24 \mathrm{~h}$ in sterile distilled water prior to sowing in the infested soil.

TABLE 7. Total amount of isothiocyanates (ITCs) extracted from the plant residues

\begin{tabular}{lc}
\hline Plant residue & Amount of ITCs $\left(\mu \mathrm{mol} \mathrm{g}^{-1}\right.$ residue $)$ \\
\hline Saori & 13.626 \\
Nabana & 2.743 \\
Taina & 2.315 \\
Ayumi & 2.312 \\
Touna & 0.568 \\
Clover & 0.007 \\
Peanut & $\mathrm{ND}^{\mathrm{z}}$ \\
\hline
\end{tabular}

z Not detected. 
organisms (15). It also was reported that various fungal antagonists, including mycoparasites such as Trichoderma spp., were involved in suppression of Rhizoctonia diseases $(6,27)$. In this study, even though proliferations of soil bacteria appear to be the major principle in induced soil suppressiveness, fungal activities in the soil also apparently were amplified by soil amendment with many plant residues. Further studies are needed to determine which and how microorganisms inhibit $R$. solani in the laimosphere of sugar beet seedlings.

There was no evidence indicating that glucosinolates or ITCs are a significant factor in soil suppressiveness. Overall, the isothiocyanate content in the plant residues was not related directly to their effects on disease suppression within the range found in the plant species and cultivars tested in this study. The residue of Saori contained the highest total amount of ITCs, and this residue provided the greatest and most consistent suppression of damping-off among B. rapa residues tested. Based on the in vitro tests, volatile compounds released from the water-imbibed residues of Saori also exhibited a prominent inhibitory effect on mycelial growth of $R$. solani. However, the growth of $R$. solani also was inhibited when exposed to volatile compounds released from $500 \mathrm{mg}$ of the residue of Clover or Touna, and the latter did not induce soil suppressiveness when added to soil. It was reported that low molecular weight volatile compounds released from immature grain crop residues, including those of corn, oat, rye, barley, sorghum, and buckwheat, inhibited growth and survival of $R$. solani in soil (20). In this study, the residues of Clover and Peanut containing essentially no glucosinolates consistently induced high levels of soil suppressiveness, and suppressiveness induced by the residue of Saori was nullified by soil treatment with the antibiotics. It is possible that ITCs may not be the only inhibitory volatile compounds released from the crop residues.

In fact, the amount of glucosinolates in the residue of Saori was only $\approx 0.1$ of the amount found in $B$. napus seed meal (25). It is likely that some significant portions of glucosinolates were degraded into ITCs during the process of air drying plant materials and then lost to the atmosphere, resulting in total isothiocyanate contents that are too low to be inhibitory to the pathogen. Thus, we did not measure individual ITCs, and yet we used air-dried plant residues because it was difficult to obtain fresh materials of plants whose growing seasons are different. Besides, it was reported that the main glucosinolates found in $B$. rapa include grogoitrin (37) and 4-hydroxyglucobrassicin $(1,12)$ that do not degrade to volatile ITCs. These suggest that the results presented in this study do not accurately elucidate the role of glucosinolates in disease suppression. Inhibitory effects of volatile ITCs on the pathogen need to be reevaluated in future studies using freezedried plant materials.

The effects of soil amendment with various plant residues on disease suppression were essentially the same in two comparable paddy field soils, suggesting that fertilization history and the amount of organic matter in soil have minor impacts on soil suppressiveness. However, the comparative relationship between colonization frequency and incidence of damping-off revealed that, overall, the effects of soil amendment with residues on both saprophytic and pathogenic activities of $R$. solani were more pronounced in $\mathrm{B}_{2}$ than $\mathrm{A}_{0 \mathrm{M}}$ soil, and only the residue of $\mathrm{cv}$. Waseaburana essentially had no effect on both pericarp colonization and damping-off in $\mathrm{B}_{2}$ soil. In addition, the suppressive effects of some residues, such as Clover and Nabana, were enhanced in $\mathrm{B}_{2}$ soil. This may suggest that, when fresh plant materials are incorporated, soils receiving chemical fertilizers, as $\mathrm{B}_{2}$ soil did, support greater activities of antagonistic soil bacteria against $R$. solani than soils receiving cow manure compost as an organic fertilizer. Nonetheless, the relationship between the colonization frequency and the incidence of damping-off is useful in characterizing soils in relation to their responses to specific soil treatments.
Overall, measurement of pericarp colonization frequency did not provide reliable indices for inoculum potential to relate to disease incidence. This is primarily because the key microbial interactions for disease suppression occur in the soil or the laimosphere, and the mechanisms involved in suppression of saprophytic and pathogenic activities of $R$. solani are different. Accordingly, in the third experiment in $\mathrm{A}_{0-\mathrm{M}}$ soil, the colonization frequency was highest in nontreated soil; however, disease incidence in nontreated soil was significantly lower than that in soil amended with residue of Santousai or Shougatuna. Nevertheless, colonization frequency in nontreated soil was greatest consistently throughout the study, and there were several cases (e.g., the third experiment in $\mathrm{A}_{0-\mathrm{M}}$ soil and the third and fourth experiments in $\mathrm{B}_{2}$ soil) in which colonization by $R$. solani was less when colonization by other fungi was greater. This suggests that pericarp colonization, although not correlated with disease incidence, instead corresponds to the activity of $R$. solani inoculum in soil and is a useful index to assess its saprophytic activity in relation to the activities of other soil microorganisms.

\section{ACKNOWLEDGMENTS}

We thank the gene bank of the Ministry of Agriculture, Forestry, and Fishery for providing us with strains of $R$. solani; S. Naito of Hokkaido University for his advice on preparation of $R$. solani inoculum; Y. Uda for technical advice on chemical analysis of glucosinolates; and A. Caesar of the U.S. Department of Agriculture-Agricultural Research Service at Sidney, MT, for reviewing the manuscript.

\section{LITERATURE CITED}

1. Agerbirk, N., Peterson, B. L., Olsen, C. E., Halkier, B. A., and Nielsen, J. K. 2001. 1,4-Demethoxyglucobrassicin in Barbarea and 4-hydroxyglucobrassicin in Arabidopsis and Brassica. J. Agric. Food Chem. 49:15021507.

2. Alabouvette, C. 1986. Fusarium wilt-suppressive soils from the Chateaurenard region: Review of a 10-year study. Agronomie 6:273-284.

3. Appelqvist, L. A., and Josefsson, E. 1967. Method for quantitative determination of isothiocyanates and oxazolidinethiones in digests of seed meals of rape and turnip rape. J. Sci. Food Agric. 18:510-519.

4. Brown, P. D., Morra, M. J., McCaffrey, J. P., Auld, D. L., and Williams, J., III. 1991. Allelochemicals produced during glucosinolate degradation in soil. J. Chem. Ecol. 17:2021-2034.

5. Bulluck, L. R., and Ristaino, J. B. 2002. Effect of synthetic and organic soil fertility amendments on southern blight, soil microbial communities, and yield of processing tomatoes. Phytopathology 92:181-189.

6. Chung, Y. R., Hoitink, H. A. J, Dick, W. A., and Herr, L. J. 1988. Effects of organic matter decomposition level and cellulose amendment on the inoculum potential of Rhizoctonia solani in hardwood bark media. Phytopathology 78:836-840.

7. Cohen, M. F., Yamasaki, H., and Mazzola, M. 2005. Brassica napus seed meal soil amendment modifies microbial community structure, nitroc oxide production and incidence of Rhizoctonia root rot. Soil Biol. Biochem. 37:1215-1227.

8. Cook, R. J., and Baker, K. F. 1983. The Nature and Practice of Biological Control of Plant Pathogens. The American Phytopathological Society, St. Paul, MN.

9. Cook, R. J., Boosalis, M. G., and Doupnik, B. 1978. Influence of crop residues on plant disease. Pages 147-163 in: Crop Residue Management Systems. Am. Soc. Agron. Spec. Publ. 31, Madison, WI.

10. Craft, C. M., and Nelson, E. B. 1996. Microbial properties of composts that suppress damping-off and root rot of creeping bentgrass caused by Pythium graminicola. Appl. Environ. Microbiol. 62:1550-1557.

11. Diab, H. G., Hu, S., and Benson, D. M. 2003. Suppression of Rhizoctonia solani on impatiens by enhanced microbial activity in composted swine waste-amended potting mixes. Phytopathology 93:1115-1123.

12. Fenwick, G. R., and Mullin, W. J. 1983. Glucosinolates and their breakdown products in food and food plants. CRC Cri. Rev. Food Sci. Nutr. 18:123-201.

13. Fukui, R., Campbell, G. S., and Cook, R. J. 1994. Factors affecting the incidence of embryo infection by Pythium spp. during germination of wheat seeds in soils. Phytopathology 84:695-702.

14. Hering, T. F., Cook, R. J., and Tang, W.-H. 1987. Infection of wheat embryos by Pythium species during seed germination and the incidence of seed age and soil matric potential. Phytopathology 77:1104-1108. 
15. Hoitink, H. A. J., and Boehm, M. J. 1999. Biocontrol within the context of soil microbial communities: A substrate-dependent phenomenon. Annu. Rev. Phytopathol. 37:427-446.

16. Hoitink, H. A. J., and Fahy, P. C. 1986. Basis for the biological control of soilborne plant pathogens with composts. Annu. Rev. Phytopathol. 24:93114.

17. Hornby, D. 1983. Suppressive soils. Annu. Rev. Phytopathol. 21:65-85.

18. Ko, W. H., and Hora, F. K. 1971. A selective medium for the quantitative determination of Rhizoctonia solani in soil. Phytopathology 61:707-710.

19. Koike, S. T., and Subbarao, K. V. 2000. Broccoli residues can control Verticillium wilt of cauliflower. Calif. Agric. 54:30-33.

20. Lewis, J. A., and Papavizas, G. C. 1974. Effect of volatiles from decomposing plant tissues on pigmentation, growth, and survival of Rhizoctonia solani. Soil Sci. 118:156-164.

21. Lewis, J. A., and Papavizas, G. C. 1975. Survival and multiplication of soil-borne plant pathogens as affected by plant tissue amendment. Pages 84-89 in: Biology and Control of Soil-borne Plant Pathogens, G. W. Bruehl, ed. The American Phytopathological Society, St. Paul, MN.

22. Manici, L. M., Lazzeri, L., Baruzzi, G., Leoni, O., Galletti, S., and Palmieri, S. 2000. Suppressive activity of some glucosinolate enzyme degradation products on Pythium irregulare and Rhizoctonia solani in sterile soil. Pest Manage. Sci. 56:921-926.

23. Manici, L. M., Lazzeri, L., and Palmieri, S. 1997. In vitro fungitoxic activity of some glucosinolates and their enzyme-derived products toward plant pathogenic fungi. J. Agric. Food Chem. 45:2768-2773.

24. Mayton, H. S., Olivier, C., Vaughn, S. F., and Loria, R. 1996. Correlation of fungicidal activity of Brassica species with allyisothiocyanate production in macerated leaf tissue. Phytopathology 86:267-271.

25. Mazzola, M., Granastein, D. M., Elfving, D. C., and Mullinix, K. 2001. Suppression of specific apple root pathogens by Brassica napus seed meal amendment regardless of glucosinolate content. Phytopathology 91:673679.

26. Mazzola, M., and Gu, Y.-H. 2002. Wheat genotype-specific induction of soil microbial communities suppressive to disease incited by Rhizoctonia solani anastomosis group (AG)-5 and AG-8. Phytopathology 92:1300-1307.

27. Nelson, E. B., Kulter, G. A., and Hoitink, H. A. J. 1983. Effects of fungal antagonists and compost age on suppression of Rhizoctonia damping-off in container media amended with composted hardwood bark. Phytopathology 73:1457-1462.

28. Osburn, R., Schroth, M. N., Hancock, J. G., and Hendson, M. 1989. Dynamics of sugar beet seed colonization by Pythium ultimum and Pseudomonas species: Effects on seed rots and damping-off. Phytopathology 79:709-716.

29. Palmieri, S., Manici, L. M., and Lazzeri, I. 1997. In vitro fungitoxic activity of some glucosinolates and their enzyme-derived products toward plant pathogenic fungi. J. Agric. Food Chem. 45:2768-2773.

30. Rosa, E. A. S., and Rodrigues, P. M. F. 1999. Towards a more sustainable agriculture system: The effect of glucosinolates on the control of soilborne diseases. J. Hortic. Sci. Biotechnol. 74:667-674.

31. Rovira, A. D., and Wildermuth, G. B. 1981. The nature and mechanisms of suppression. Pages 385-415 in: Biology and Control of Take-all. M. J. C. Asher and P. Shipton, eds. Academic Press, London.

32. Scheuerell, S. J., and Mahaffee, W. F. 2004. Compost tea as a container medium drench for suppressing seedling damping-off caused by Pythium ultimum. Phytopathology 94:1156-1163.

33. Shea, S. R., and Broadbent, P. 1983. Developments in cultural and biological control of Phytophthora diseases. Pages 335-350 in: Phytophthora: Its Biology, Taxonomy, Ecology and Pathology, D. C. Erwin, S. Bartnicki-Garcia, and P. Tsao, eds. The American Phytopathological Society, St. Paul, MN.

34. Talalay, P., Zhang, Y., Cho, C., and Posner, G. H. 1992. Spectroscopic quantification of organic isothiocyanate by cyclocondensation with vicinal dithiols. Anal. Biochem. 205:100-107.

35. Tenuta, M., Conn, K. L., and Lazarovits, G. 2002. Volatile fatty acids in liquid swine manure can kill microsclerotia of Verticillium darliae. Phytopathology 92:548-552.

36. Thurston, H. D. 1997. Slash/mulch systems in the Americas. Pages 31-72 in: Slash/Mulch Systems: Sustainable Methods for Tropical Agriculture, H. D. Thurston, ed. Westview Press, Boulder, CO.

37. VanEtten, C. H. 1969. Goitrogens. Pages 103-142 in: Toxic Constituents of Plant Foodstuffs. I. E. Liener, ed. Academic Press, New York.

38. Zhou, X. G., and Everts, K. L. 2004. Suppression of Fusarium wilt of watermelon by soil amendment with hairy vetch. Plant Dis. 88:13571365. 